\title{
POCZUCIE TOŻSAMOŚCI MIESZKAŃCÓW MAŁEGO MIASTA GALICYJSKIEGO (W DRUGIEJ POŁOWIE XIX WIEKU) ${ }^{1}$
}

\author{
Jadwiga Hoff \\ Uniwersytet Rzeszowski
}

\begin{abstract}
SENSE OF IDENTITY OF THE INHABITANTS OF A GALICIAN TOWN (IN THE SECOND HALF OF THE $19^{\text {TH }}$ CENTURY)
\end{abstract}

Small Galician towns had a very varied social structure. Their inhabitants formed a strictly hierarchical community. People socialized exclusively with the members of their own particular social group. One thing that united all, both those from "high society" and those standing at lower levels of the social ladder, was an unfavorable attitude towards the people living in the country, arising from townspeople's conviction of their own "superiority." Besides, those from the country did not consider themselves equal to townsfolk, whom they regarded as "gentlepeople." A significant proportion of the small town community were Jews (in Western Galicia from slightly above 37\% in 1880 to $33 \%$ in 1910; in the towns of Eastern Galicia from $44.6 \%$ to $43.6 \%$ respectively). The second largest religious-ethnic group among Eastern Galician small town residents were Ruthenians-Ukrainians (about 30\%). The smallest community were the Roman Catholics, identified with Poles (from $23 \%$ in 1880 to more than $26 \%$ in 1910). In all small towns the Christians and the Jews formed separate communities, whose interactions were mostly business-related. In the small towns of Eastern Galicia, where one third of the population comprised of Ruthenians, both they and the Poles, but also the Jews, had a strong sense of localness, which effectively reduced ethnic tensions. The spread of national ideas in the last years of the $19^{\text {th }}$ century changed this situation; it substantially weakened the previous bonds between people within neighboring local communities. Already at the turn of the $19^{\text {th }}$ and $20^{\text {th }}$ century the inhabitants of small Eastern Galician towns ceased to be the locals; they became either Poles or Ukrainians.

Key words: Galicia, small towns, small town community, social and professional structure, Ruthenians-Ukrainians, Poles, Jews, identity.

Słowa kluczowe: Galicja, małe miasta, społeczność małomiejska, struktura społeczno-zawodowa, Rusini-Ukraińcy, Polacy, Żydzi, tożsamość.

${ }^{1}$ Tekst powstał na podstawie wyników badań, które zostały zaprezentowane przez autorkę we wcześniejszych publikacjach, m.in. w książkach: Społeczność małego miasta galicyjskiego w dobie autonomii, Rzeszów 1992; Mieszkańcy małych miast Galicji Wschodniej w okresie autonomicznym, Rzeszów 2005.

Adres do korespondencji: hoffowie@gmail.com 
W Galicji przeważającym typem miasta było miasto małe lub miasteczko. Małe miasta, które są przedmiotem niniejszych rozważań, liczyły 2000-5000 mieszkańców, utrzymujących się - z nielicznymi wyjątkami - z zajęć pozarolniczych. Ponadto, w przeciwieństwie do miasteczek, pełniły one funkcje usługowe w zakresie handlu, kredytu, sądownictwa, oświaty, kultury itp., gdyż w większości z nich mieściły się siedziby władz skarbowych, sądowniczych, szkolnych, a także politycznych i administracyjnych. Wśród mieszkańców znaczny odsetek stanowili Żydzi, przy czym większe ich skupienie obserwuje się we wschodniej części Galicji. Podczas gdy w małych miastach Galicji Zachodniej odsetek ludności żydowskiej wynosił przeciętnie od nieco ponad 37\% w 1880 roku do 33\% w roku 1910, to w Galicji W schodniej w tym samym czasie - od 44,6\% do 43,6\%. W małych miastach wschodniogalicyjskich drugą co do wielkości grupą mieszkańców była utożsamiana z Rusinami ludność obrządku greckokatolickiego, która w okresie autonomii stanowiła około 30\%. Ludność rzymskokatolicka była najmniej liczna, ale jej odsetek systematycznie, choć powoli wzrastał - od 23\% w 1880 roku do ponad 26\% w roku 1910 .

\section{TOŻSAMOŚĆ „KLASOWA” I ZAWODOWA}

O strukturze społeczno-zawodowej mieszkańców małych galicyjskich miast pisałam już wielokrotnie ${ }^{2}$, wobec tego nie będę rozwijała szerzej tego zagadnienia. Chciałabym natomiast zająć się relacjami między poszczególnymi grupami społecznymi i zawodowymi. Niewątpliwie mieszkańcy małych miast, dzięki zamieszkiwaniu w tym samym miejscu i rozlicznym interesom, tworzyli jakąś formę wspólnoty, ale była to wspólnota ogromnie zhierarchizowana. Na szczycie hierarchii stał dawny właściciel miasteczka lub jego potomkowie. Zarówno on, jak i całe „obywatelstwo ziemskie" zamieszkujące okoliczne dwory, utrzymywali stosunki towarzyskie wyłącznie między sobą. Od mieszkańców miasta izolowali się; trzymali się z daleka nawet od przedstawicieli inteligencji, których uznawali „za niegodnych tego zaszczytu [bywania w towarzystwie szlachty], bo niższych w hierarchii społecznej od nich"3. Jeden z autorów analizowanych przeze mnie pamiętników wspomina swoją niezamężną ciotkę, która straciła niewielki majątek i musiała zamieszkać w mieście, ale bardzo ją to bolało, „uważała się za zdeklasowaną"4. Podobne odczucia mieli jego rodzice. Ojciec posiadał wcześniej majątek ziemski, który został sprzedany, i rodzina osiadła w mieście. „Nie weszliśmy jednak do sfer mieszczańsko-urzędniczych, chociaż nie należeliśmy już do ziemiaństwa" - pisze autor wspomnień. Rodzice, co

${ }^{2}$ Zob. m.in. J. Hoff, Społeczność..., s. 32-44; eadem, Mieszkańcy..., s. 61-76.

${ }^{3}$ Zob. m.in. M. Orłowicz, Moje wspomnienia turystyczne, Wrocław-Warszawa-Kraków 1970, s. 74; Zakład Narodowy im. Ossolińskich we Wrocławiu (dalej: ZNiO), sygn. 15393: S. O to w ski, Moje wspomnienia [z lat 1896-1963], k. 43; sygn. 15587: M. B an ach, Wspomnienia z lat 1897-1969, t. 1, vol. 2, k. 8; sygn. 15327/1: M. B a r a ń s k i, Opowieść o jednym miasteczku i jednej rodzinie [Wspomnienia obejmujące okres od połowy XIX w. do 1978 r.], cz. 1, k. 73.

${ }^{4} \mathrm{ZNiO}$, sygn. 15394: T. Porembalski, Wspomnienia [z lat 1896-1960], t. 1, k. 28. 
prawda, utrzymywali stosunki towarzyskie $\mathrm{z}$ wieloma rodzinami urzędniczymi, ale uważali się za kogoś lepszego, traktując gości z dostrzegalną nutą protekcjonalności ${ }^{5}$.

Stosunek inteligencji z ziemiańskimi korzeniami do urzędników niewiele odbiegał od stosunku urzędników wywodzących się z niższych kręgów społecznych do osób z dawnego środowiska. Po zdobyciu wykształcenia i stanowiska nie kryli oni niechęci do dawnych pobratymców, „mając ich za coś od siebie niższego”. Doskonale obrazuje to scena opisana w jednej z lokalnych gazet, w której główne role zagrali urzędnik magistracki i stolarz, stryjeczny brat tegoż. Gdy stolarz przyszedł zaprosić krewnego na wesele, usłyszał: „Otóż to zachciałeś, na co tobie inteligencję spraszać na wesele? Weź sobie równego, stolarza albo innego rzemieślnika, to dla ciebie od-

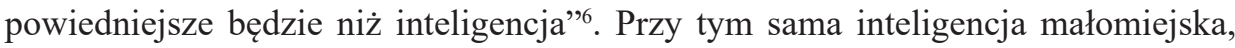
mimo że niezbyt liczna, była tworem ogromnie zróżnicowanym. Według ówczesnych wyobrażeń „wierzchołek towarzystwa” tworzyli reprezentanci władz politycznych, wojskowych, a także sądowniczych (,,pan starosta i jenerał wojsk"). Blisko nich skupiali się „rozmaitej maści naczelnicy”, a dalej „rozlewał się strumień przeznaczony dla innych mniejszych, ale zawsze jeszcze grubych ryb", takich jak dyrektor gimnazjum, komisarz skarbowy, adiunkt sądowy, adwokat, notariusz, profesor gimnazjalny, przedstawiciele duchowieństwa, głównie rzymskokatolickiego. W dużym od tych grup oddaleniu znajdowali się urzędnicy najniższych rang i nauczyciele szkół ludowych, którym zresztą często odmawiano prawa nazywania się „inteligencją"”. Z urzędnikami pocztowymi czy podatkowymi, z nauczycielami szkół ludowych „nie żyło się"; nie bywało się u nich, nie zapraszano ich na przyjęcia, bo - jak z przekąsem pisał Mieczysław Orłowicz - „cóż by na to powiedziała jakaś obecna tam pani radczyni czy pani mecenasowa”. Ukończenie gimnazjum czy seminarium nauczycielskiego nie dawało tytułu do tak wysokiego awansu społecznego, aby bywać na tych samych przyjęciach, w których uczestniczyli absolwenci prawa czy medycyny ${ }^{8}$. Pilnie też baczono, aby zachować towarzyską odrębność w kontaktach z podwładnymi - urzędnikami zajmującymi niższe miejsce w hierarchii. Przełożeni i podwładni spotykali się na imprezach publicznych, ale na gruncie prywatnym takie spotkania były wykluczone, ponieważ mogłyby doprowadzić do ,pewnego rodzaju spoufalenia i lekceważenia przełożonego" ". Mimo tych wewnętrznych różnic wszyscy przedstawiciele inteligencji małomiejskiej uważali się jednak za „wyższe społeczeństwo”. Pozostali mieszkańcy stanowili w ich oczach „resztę ludności”, od której odgradzali się także w sensie fizycznym. Absolutna odmowa wspólnego uczestnictwa w imprezach publicznych (jak chociażby różnego rodzaju uroczystościach patriotyczno-narodowych, przedstawieniach amatorskich, występach chórów) zdarzała się rzadko, ale przedstawiciele inteligencji biorący w nich udział zasiadali oddzielnie, zajmując pierwsze rzędy; dalsze przeznaczone były dla mieszczan. Nawet kościół nie był wol-

5 Ibidem.

6 „Gazeta Podkarpacka” 1875, nr 64.

7 Zob. J. Hoff, Mieszkańcy..., s. 78.

${ }^{8}$ M. Orłowicz, op. cit., s. 75.

${ }^{9}$ Zob. J. Hoff, Mieszkańcy..., s. 78; także: J. S z y m c zak-Ho ff, Życie towarzyskie i kulturalne Rzeszowa w dobie autonomii Galicji, Rzeszów 1993, s. 234-235. 
ny od podobnych zachowań. Zwykle mieszczanie gromadzili się w nawie, przedstawiciele okolicznego ziemiaństwa zasiadali w ławie kolatorskiej, a urzędnicy albo w prezbiterium oddzielonym od nawy balaskami, albo na zarezerwowanych dla nich miejscach w pobliżu ambony. Również przy wchodzeniu do świątyni mieszczanie nie mieli fizycznego kontaktu z przedstawicielami elit, ponieważ ci pierwsi wchodzili głównym wejściem, a drudzy przez zakrystię ${ }^{10}$.

Część „reszty ludności”, stojąca na najniższych szczeblach drabiny społecznej, myśląca głównie o tym, jak przeżyć kolejny dzień, akceptowała taki układ. Drobnomieszczanie natomiast, w źródłach określani jako mieszczaństwo, za prawdziwych mieszczan uważali wyłącznie rzemieślników - majstrów cechowych wraz z rodzinami. Zajmujący się handlem, z racji swojej odrębności wyznaniowej i kulturowej, przez chrześcijańskich na ogół rzemieślników sytuowani byli poza „prawdziwym mieszczaństwem". Za takie nie uważano też inteligencji, która stanowiła w dużej mierze element napływowy, a więc obcy. Przybyli z różnych stron nowi mieszkańcy nie byli związani żadną tradycją z przeszłością miasta, nie byli z nim też związani żadnymi związkami rodzinnymi. To rodziło niechęć i nieufność, powodowało, że rodzima ludność przez długie lata nie akceptowała przybyszów. Znalazło to nawet odbicie w języku potocznym. Dla przykładu - w Żywcu urzędników, lekarzy i prawników, którzy najczęściej przybywali z zewnątrz, nazywano „przystacami”, a w Lesku - „zawłokami” ${ }^{11}$. Jedynym, co łączyło wszystkich mieszkańców miast, zarówno tych wywodzących się z „towarzystwa”, jak i „reszty ludności”, była niechęć do mieszkańców wsi, wynikająca z przeświadczenia o „lepszości” w związku z przynależnością do stanu miejskiego. Zresztą sami chłopi nie uważali się za równych mieszkańcom miast; postrzegali tych ostatnich jako „panów”12. Przeświadczenie o „lepszości” przejawiało się między innymi w przekonaniu, że małżeństwa „międzystanowe” są klasycznym mezaliansem. Niepodobieństwem było małżeństwo syna majstra z chłopską córką, nawet majętną i wykształconą. Na pytanie, czy to prawda, że syn ma się żenić z chłopką, „pan szewc przetarł ręką czoło i powiada - Co? Ja miałbym syna żenić z chłopską córką? Chyba by się świat miał zapaść”. Na argumentację zaś, że dziewczyna „ma ładny majątek, jest pracowita, ukończyła czwartą klasę [...], a syn twój przecie i pierwszej nie skończył”, majster odrzekł: „Niechta nie umie czytać, ale jest rzemieślnikiem i mieszczańskim synem! To nie idzie w porównanie z jej urodą, majątkiem i czwartą klasą! Ożenić go z nią to tak wyglądałoby, jak do powozu konia z wołem zaprzęgnąć"13. Tak więc z przynależnością do stanu miejskiego przegrywało nawet wykształcenie, mimo że w Galicji, już po reformach Michała

${ }^{10}$ J. Hoff, Mieszkańcy..., s. 79.

${ }^{11}$ Ibidem, s. 79-80; J. Hoff, Społeczność..., s. 97.

${ }^{12}$ Andrzej Czechowicz, wiejski chłopak z Wysokiej, tak opisywał swoje pierwsze wrażenia po przyjeździe do Łańcuta na naukę w tamtejszym gimnazjum: „Tam [w mieście] siedzą panowie, nic nie robią, chodzą na spacer, dobrze jedzą, mówią ciągle o Polsce. [...] Ludzie w mieście ubierają się po pańsku i noszą krawaty, jedzą po pańsku widelcem, mówią po pańsku, całują kobiety w rękę" (A. C z e c h o w i c z, Droga do szkoły [w:] Gimnazjum i Liceum im. Henryka Sienkiewicza w Lańcucie. Szkice historyczne, sylwetki, wspomnienia, Warszawa 1965, s. 241).

13 J. S k ła d z i eń, Za ciasnym wydawał mi się ten zakątek. Pamiętniki, Kraków 1982, s. 43. 
Bobrzyńskiego, ponad 40\% osób, a według innych szacunków nawet ponad $50 \%$, nie umiało ani czytać, ani pisać.

\section{STOSUNKI WYZNANIOWO-NARODOWOŚCIOWE}

Stosunki pomiędzy poszczególnymi grupami wyznaniowo-narodowościowymi układały się różnie. We wszystkich omawianych miastach Żydzi i chrześcijanie stanowili odrębne społeczności. Kontaktowały się one głównie na gruncie ekonomicznym; rzadko mamy do czynienia z kontaktami na gruncie społecznym. Powstające pod koniec XIX wieku stowarzyszenia kulturalno-oświatowe i o charakterze gospodarczym miały wyraźne oblicze wyznaniowo-narodowościowe. Bardzo rzadko źródła odnotowują obecność przedstawiciela społeczności żydowskiej na przykład w jakimś komitecie organizacyjnym. Do pewnej współpracy dochodziło w instytucjach samorządowych, lecz kontakty sąsiedzkie, a zwłaszcza koleżeńskie, czasem towarzyskie, chrześcijanie ${ }^{14}$ (dotyczyło to jednak niewielkiej grupy osób) utrzymywali jedynie z tymi Żydami, którzy w mniejszym lub większym stopniu zasymilowali się do kultury polskiej ${ }^{15}$ lub - rzadziej - ruskiej ${ }^{16}$. Żydzi (w małych miastach byli to głównie chasydzi) jawili się przedstawicielom społeczności rzymskich katolików jako nieucywilizowana, obca, choć swoja, masa. Zarzucano im brak kultury, zdzierstwo, hołdowanie zabobonom i przesądom, życie w nieporządku i brudzie. Drażnił ich strój, sposób zachowania, kaleczenie języka polskiego itp. Przede wszystkim jednak zarzucano im, że nie zajmują się ,pracą rzeczywiście produkcyjną”. W prasie z lat 70 . i 80. XIX wieku spotykamy teksty, w których ubolewano, ,jak mały procent Żydów zajmuje się czy to pracą umysłową, czy rzemiosłami, czy też nareszcie rzeczywistym gospodarstwem rolnym. Większa ich część żyje z handlu [...]"17. Na podobne wypowiedzi natykamy się kilkanaście czy dwadzieścia parę lat później: „handlem zawładnęli Żydzi, a to przecież podstawa egzystencji miast”. Galicyjskie miasta są miastami żydowskimi, przydomek ten zaś ,,równa się wzgardzie i upadkowi, a przede

14 Myślę tu głównie o rzymskich katolikach. Skąpość źródeł nie pozwala na szersze rozważania o tym, jak wyglądały stosunki między społecznością żydowską a greckokatolicką, chociaż zaobserwować tu można pewną solidarność, która - jak się wydaje - wynikała z poczucia dyskryminacji ze strony społeczności polskiej.

${ }_{15}$ Takich Żydów w małych miastach było niewielu. Wprawdzie procesy asymilacyjne w duchu polskim rozpoczęły się wśród Żydów galicyjskich już ok. 1870 r., ale najbardziej były one widoczne w dużych miastach. W małych miastach i miasteczkach Żydzi w swej masie aż do końca monarchii, a także i później, żyli w izolacji od chrześcijańskiego otoczenia. Pewne tendencje asymilacyjne można zaobserwować jedynie wśród wąskiej grupy inteligencji i bogatego mieszczaństwa.

${ }^{16}$ Przypadki ukrainizacji Żydów były rzadkie, ponieważ ludowa kultura ukraińska okazała się dla nich mało atrakcyjna, a ponadto tylko znajomość języka polskiego pozwalała na udział w życiu kulturalnym, społecznym, politycznym. Jedynie tam, gdzie Żydzi żyli w językowym otoczeniu ruskim (np. w Zabłotowie), można było spotkać przypadki ciążenia do kultury ukraińskiej. Por. J. Ho 1 z e r, Asymilacja i akulturacja Żydów galicyjskich, „Więź” R. 32, 1989, nr 4, s. 109.

17 „San” 1879, nr 48; „Kurier Rzeszowski” 1889, nr 2. 
wszystkim zatracie charakteru narodowego"18. Głównym jednak „grzechem” Żydów było to, że są Żydami i że czują się Żydami; zaledwie bardzo mała cząstka inteligencji żydowskiej czuje się Polakami - pisał pod koniec XIX wieku autor artykułu na temat kwestii żydowskiej ${ }^{19}$. Zauważył on jednak, że „ostatnimi laty widoczny jest wprawdzie pewien postęp ku polonizowaniu się Żydów, uważają oni już więcej na czystość języka, dzieci uczą po polsku - ale dalej też nie idą. Wiele młodzieży żydowskiej mówi poprawnie po polsku, lecz jeszcze po polsku nie czuje [...]". Nie należy się więc dziwić, że Polacy patrzą na Żydów z uprzedzeniem i nie dowierzają im: „Jak długo między Żydami nie rozpowszechni się przekonanie, że wyznanie religijne nie jest cechą odrębności narodowej, tak długo nie zatrze się różnica między nimi a innymi wyznaniami, tak długo my im niedowierzać będziemy"20.

Cytat ten dobrze ilustruje stosunki między Polakami a Żydami - niedowierzanie, nieufność, wzajemne pretensje były na porządku dziennym. $Z$ jednej strony przejawy bliskości, czy choćby tylko sympatii zdarzały się zbyt rzadko ${ }^{21}$, aby mogły zlikwidować granicę między sztetlem a resztą miasta. Z drugiej strony sami Żydzi niczego nie ułatwiali nieżydowskim mieszkańcom Galicji. Galicja była dla Żydów miejscem, w którym żyli, zakładali rodziny, chowali swoich zmarłych, ale czuli się tu tylko gośćmi: „Człowiek jest tylko gościem na ziemi [...], Żydzi są podwójnie gośćmi, bo przebywają nie na swojej ziemi" ${ }^{22}$. Słowa, włożone w usta Szlomy Abu Darhama przez Juliana Stryjkowskiego, są - moim zdaniem - wiernym odzwierciedleniem postawy Żydów, która w zasadniczy sposób rzutowała zarówno na ich styl życia, jak i na stosunki z nieżydowskimi mieszkańcami Galicji. Żydzi sami odgradzali się od wpływów innych religii i nacji, by nie stwarzać warunków do przenikania wzorców kulturowych z zewnątrz ${ }^{23}$, co powodowało, że dla nieżydowskich mieszkańców miast i miasteczek świat starozakonnych pozostawał nieznany, tajemniczy, trudno dostępny. Rodziło to nie tyle ciekawość i chęć poznania, ile niechęć, a nawet wrogość. Żydzi dla nie-Żydów byli obcy; należeli do rodzimego pejzażu i kultury, ale nie uważano, że są u siebie. Polacy ich cenili (co wcale nie znaczyło, że traktowali jako swoich) tylko wówczas, gdy zasymilowali się do kultury polskiej i stawali się polskimi patriotami. Jako członkowie społeczności żydowskiej i wyznawcy religii mojżeszowej pozostawali obcy; swoi, ale obcy.

18 „Sądeczanin” 1902, nr 17.

19 „San” 1879, nr 48.

20 Ibidem.

21 Z bezwarunkową akceptacją Żydów spotkałam się w jednym tylko źródle - we wspomnieniach ks. Michała Banacha, który dzieciństwo i młodość spędził w Kopyczyńcach wśród żydowskich kolegów i przyjaciół - ZNiO, sygn. 15587: M. Banach, op. cit., k. 5.

22 J. S tryj k ow s k i, Przybysz z Narbony, Warszawa 1983, s. 290.

23 Pisał o tym m.in. I. S in ge r, ...poeta wygnania [wywiad przedrukowany z „Le Monde”], ,Polityka” R. 26, 1982, nr 40, s. 9. Zob. także I. B e r li n, Żydzi-od zniewolenia do emancypacji, „Znak” R. 35, 1983, nr 2-3, s. 500; K.D. S z atraw s ki, Życie i tradycja Żydów w powieściach galicyjskich Juliana Stryjkowskiego [w:] Kresy i pogranicza. Historia, kultura, obyczaje, red. nauk. Z. F r a s, A. S t a n i s ze w s k i, Olsztyn 1995, s. 212-213; O. G o l d b e r g-M u 1 k i e w i c z, Księga pamięci (,,Memorbuecher”) a mit żydowskiego miasteczka, „Etnografia Polska” 1991, t. 35, z. 2, s. 187-199; e a d e m, Stara i nowa ojczyzna. Ślady kultury Żydów polskich, Łódź 2003, s. 60, 64, 68. 
Egzystencja mieszkańców małych miast Galicji Wschodniej bardzo przypominała tę, jaka była udziałem mieszkańców podobnej wielkości miast zachodniogalicyjskich. Jedno, co je zdecydowanie różniło, to ich skład narodowościowy. Małe miasta Galicji Wschodniej zamieszkiwali, oprócz Żydów i Polaków, Rusini, którzy stanowili przeciętnie 1/3 całej populacji, ale ich tożsamość narodowościowa kształtowała się powoli. Andrzej Chciuk, wspominając doktora Czubatego, drohobyckiego weterynarza, napisał, że „do końca życia nie mógł jakoś rozstrzygnąć kwestii: czy był Polakiem, czy Rusinem, bo termin »Ukrainiec « w ogóle do niego nie docierał". „Ta ja naprzód zdaji si jezdym drohobyczaninem” - mawiał nieraz ${ }^{24}$. Wydaje się, że podobnie było z wieloma innymi mieszkańcami małych wschodniogalicyjskich miast, zwłaszcza z przedstawicielami inteligencji. Czuli się oni przede wszystkim bohorodczaninami, borszczowianinami, brzozowianinami, chodorowiczaninami, kosowianinami; pochodzili z Dobromila, Leska, Kulikowa, Zabłotowa czy Jagielnicy.

Mieszkańcy Galicji Wschodniej aż do końca XIX wieku, a nawet i później, mieli silne poczucie tutejszości ${ }^{25}$. Kategoria „tutejszości” przez długi czas skutecznie niwelowała napięcia na tle narodowościowym. Dopiero upowszechnienie idei narodowych zmieniło sytuację - osłabiło dotychczasowe więzi łączące ludzi w ramach sąsiedzkich wspólnot lokalnych. Mieszkańcy Galicji Wschodniej, w tym także mieszkańcy małych wschodniogalicyjskich miast, powoli przestawali być „tutejsi”; stawali się Polakami i Ukraińcami.

Józef Doboszyński, wychowany i aż do końca XIX wieku żyjący w Galicji Wschodniej, twierdził, że początek rozłamu między Polakami i Rusinami datować należy na 1848 rok. Dowodził, że przed 1848 rokiem Rusina od Polaka różnił tylko obrządek (sam, wychowany w obrządku greckokatolickim, czuł się Polakiem) i nikomu do głowy nie przychodziło identyfikowanie obrządku z narodowością. Wspominając lata 40. XIX wieku, kiedy pobierał nauki w gimnazjum w Samborze, pisał, że wśród młodzieży gimnazjalnej nie znano wówczas podziału na Polaków i Rusinów; zresztą, „w klasie inteligentnej uważał się każdy za Polaka”, w mieście powszechnie używano języka polskiego. Język ruski traktowano jako gwarę ludową, tak że nawet księża ruscy „z lepszą inteligencją” używali w domu języka polskiego, a bywało, że i w cerkwi głosili kazania po polsku². Doboszyński, a należy przypuszczać, że był on wyrazicielem opinii przynajmniej części środowiska, w którym się obracał (notariusze, adwokaci, sędziowie, inni urzędnicy), zupełnie nie rozumiał idei ruskiego (później nazywanego ukraińskim) ruchu narodowego i „odkrycie” przez Rusinów własnej odrębności traktował jako wewnętrzną dywersję. To oburzenie i pogardę daje się wyczuć także w jego odnoszeniu się do współpracowników ruskiego pochodzenia. O urzędnikach Polakach, zresztą ogólnie o Polakach, pisał ciepło i z uznaniem; tak samo o nielicznych Żydach zasymilowanych do kultury polskiej. Dobrego słowa nie

${ }^{24}$ A. Ch c i u k, Atlantyda. Opowieść o Wielkim Księstwie Bałaku, Łomianki 2015, s. 30.

${ }_{25}$ Doskonale ukazała to H. A u d e r s k a w powieści Ptasi gościniec, Warszawa 1979.

${ }^{26}$ J. D o b o s z y ń s k i, Pamiętnik [w:] Pamiętniki urzędników galicyjskich, przyg. do dr. I. H o mo 1a, B. Ło pus zańs k i, Kraków 1978, s. 362, 364-365, 372-373. Doboszyński był klasycznym przykładem zjawiska określanego mianem gente Rutheni, natione Poloni, zob. A. Ś w i ą t e k, Gente Rutheni, natione Poloni. Z dziejów Rusinów narodowości polskiej w Galicji, Kraków 2014. 
miał natomiast dla urzędników Rusinów podkreślających swoją odrębność narodową. Określał ich obraźliwym mianem „chruń” albo „fanfaron”27.

O tym, że stosunki między Polakami a Rusinami „popsuł” rok 1848, możemy przeczytać także $w$ innych pamiętnikach ${ }^{28}$. Tadeusz Porembalski przytacza w swoich wspomnieniach słowa swego wuja, który zwykł mawiać, że „Bóg stworzył wszystkich ludzi, z wyjątkiem Ukraińców, a tych wyjątkowo hr. Stadion"29. Także Józef Borodzicz twierdził, że w 1848 roku „stworzono sztucznie narodowość ruską" ${ }^{30}$. Obie te opinie to skądinąd nawiązanie do znanej wypowiedzi przypisywanej Florianowi Ziemiałkowskiemu ${ }^{31}$, która w licznych kręgach polskich w Galicji, a także i później, stała się poglądem obiegowym.

W zasadzie wszyscy autorzy wykorzystanych przeze mnie pamiętników jak mantrę powtarzają, że stosunki między ludnością polską i ruską zdecydowanie pogorszyły się po 1848 roku, ale sami piszą o Rusinach w sposób przyjazny, a nawet pochlebny, jakkolwiek z wyraźnie wyczuwalną nutą wyższości nad współmieszkańcami wyznającymi inną religię, mówiącymi innymi językami, kultywującymi inne zwyczaje i obyczaje. Wynikało to z obecnej w życiu społecznym idei polskiego hegemonizmu kulturowego wyznawanego przez inteligencję polską, a przynajmniej znaczną jej część (idea ta przetrwała zresztą dłużej niż sama Galicja). Tadeusz Fabiański w swoim pamiętniku chwalił ruską poetkę Nataliję Kobrynśką, z którą przyjaźniła się jego

27 J. D o b o s zy ń s k i, op. cit., s. 366, 396-397, 399, 402, 405.

${ }^{28}$ Zob. ZNiO, sygn. 15327/1: M. B arański, op. cit.; St. K[a rw o w s k i], Cztery tygodnie w Galicji, Poznań 1891; ZNiO, sygn. 15394: T. P or e m bals ki, op. cit.; J. B or od zi c z, Na Rusi galicyjskiej schyzma się gotuje!: z pamiętników..., Chrzanów 1911.

${ }^{29}$ ZNiO, sygn. 15394: T. P o r e m bals k i, op. cit., k. 19.

${ }^{30}$ J. B or o d zi c z, op. cit., s. 47.

31 Z. Fras, Florian Ziemiałkowski (1817-1900). Biografia polityczna, Wrocław-Warszawa-Kraków 1991, s. 53-54. Zob. F. Ziemiałkowski, Pamiętniki, cz. 1, Kraków 1904, s. 12: „W komisji tej [konstytucyjnej], gdy Czechy (Palacky, Pinkas, Rieger) uczynili wniosek podziału Galicji na dwie prowincje: polską i ruską [...] - musiałem sam jeden bronić całości kraju”, bo „czy Rusini są narodem? U nas naród nie oznacza tego, co ród albo lud. W logicznym polskim języku naród ma polityczne znaczenie i często a sprawiedliwie za państwo się bierze. [...] Rusini tworzyli różne państewka lub byli częścią innego państwa, Rusini jako tacy nigdy nie byli państwem ruskim, dlatego w naszym pojęciu tego wyrazu nie są Narodem" (ibidem, cz. 4: Rok 1863, Kraków 1904, s. 192). Zob. także: A. D u n i n B o r k o w s k i, Sejm ustawodawczy rakuski ze szczególniejsza uwaga na poselstwo polskie, cz. 2, Poznań 1850 - autor, relacjonując wspomniane wystąpienie Ziemiałkowskiego, pisał: „Podburzanie Niemców i Żydów przeciw Polakom nie dało się rozdmuchać w Galicji, jak w Księstwie Poznańskim. Dopiero przypomina sobie Stadion, że prawie połowa mieszkańców tej części Polski, która po rozbiorze dostała się Austrii, jest greckiego obrządku. W tej chwili powstaje w nim myśl polityczna, genialna, mająca spłodzić nie tylko nowy adres, ale nawet nową narodowość [s. 65]. [...] Więc Stadion udaje się do konsystorza, powiada mu: Najpierwszym uzyskaniem rewolucji jest równe uprawnienie narodowości; wola narodów ma być spełnianą na przyszłość. Wy jesteście podbitym i przez Polaków uciskanym narodem, co was obchodzi Polska? Myślcie o sobie, bo teraz pora. Prawa, o jakie upomina się na mocy narodowości polska deputacja w Wiedniu, wam się wyłącznie należą" [s. 70]. [...] Kiedy w komisji konstytucyjnej przyszedł pod obrady podział Polski austriackiej, o jaki upominali się Ruteńce, na mocy narodowości Stadionowskiej, a członkowie tej komisji nieświadomi naszych stosunków byli w wątpliwości, wyświetlił im Ziemiałkowski ten przedmiot ze strony historycznej, politycznej, prawnej i rozumowej [s. 93]". 
ciotka, że „świetnie mówiła po polsku, jak rodowita Polka"32. Marian Barański wspomina, że jego ojciec bardzo się przyjaźnił z adwokatem leskim Janem Strutyńskim, który był Rusinem, ale „uważał się za Polaka i po rusku nigdy nie mówił”33. Tadeusz Porembalski, przywołując na kartach swoich wspomnień dzieciństwo spędzone w Starej Soli, pisze, że wśród osób odwiedzających dom jego rodziców byli także Rusini, między innymi proboszcz unicki z żoną, Węgierką z pochodzenia, których określił jako dziwnych, ponieważ mimo że ,inteligentni, muzykalni, dobrze wychowani, robili jednak politykę ukraińską"34. Chwalił księży katolickich i unickich z Leska, gdzie rodzice autora wspomnień przenieśli się w 1905 roku, że nie politykowali, ale swoim postępowaniem dawali przykład zgodnego współżycia między oboma obrządkami. Co prawda, było już słychać, że po wsiach księża ruscy „zaczynali podnosić głos i prowadzili ruch ukraiński”, ale w Lesku stosunki między katolikami i unitami były co najmniej poprawne ${ }^{35}$. O życiu w zgodzie i wręcz sąsiedzkiej przyjaźni Polaków i Rusinów czytamy we wspomnieniach ks. Michała Banacha. W Kopyczyńcach, gdzie spędził dzieciństwo i wczesną młodość, było wiele rodzin polsko-ruskich, dlatego m.in. święta Bożego Narodzenia obchodziło się podwójnie, śpiewając zgodnie Bóg się rodzi obok Boh predwicznyj. Także w uroczystościach pogrzebowych uczestniczyli razem księża polscy i uniccy, odprawiając modły każdy w swoim obrządku ${ }^{36}$. Podobnie zachowywali się księża obu obrządków w innych miastach. Pisali o tym sami Rusini. Z relacji Stefanii Abrahamowskiej, córki znanego ruskiego działacza kulturalno-oświatowego w Mikulińcach, dowiadujemy się, że ceremonię zaślubin jej siostry prowadzili miejscowy paroch i dwaj polscy duchowni, którzy asystowali duchownym greckokatolickim przy ołtarzu ${ }^{37}$. Informacje o wpływie księży obu wyznań na dobre stosunki między Polakami a Rusinami, mieszkającymi w małych wschodniogalicyjskich miastach, przynosi także ówczesna prasa lokalna ${ }^{38}$.

Polacy i Rusini spotykali się nie tylko na gruncie prywatnym i w świątyniach. Wspólnie uczestniczyli też w różnych przedsięwzięciach kulturalnych. Stefan Otowski wspomina, że do kasyna w Żurawnie należeli wszyscy inteligenci z miasteczka bez różnicy obrządku ${ }^{39}$. O przynależności Rusinów do kasyna w Lesku wspomina z kolei Tadeusz Porembalski, ale - jak wynika z jego przekazu - kasyno miało polski charakter i ,jeśli nawet Rusini należeli do takich towarzystw - wszędzie na prowincji należeli - to stosowali się do zwyczajów miejscowych [czyli polskich]" ${ }^{{ }^{40}}$. Potwierdza to jego ojciec Jan Porembalski, pisząc, że niektórzy Rusini brali udział „W naszym [czyli polskim] życiu”, przy czym było dla niego oczywiste, że nale-

${ }^{32} \mathrm{ZNiO}$, sygn. 15450: T. F a b i a ń s k i, Ze wspomnień bolechowskich, k. 6.

${ }^{33} \mathrm{ZNiO}$, sygn. 15327/1: M. B a ra ń s ki, op. cit., k. 111-112.

${ }^{34}$ ZNiO, sygn. 15394: T. P o r e m b a l s k i, op. cit., k. 31.

35 Ibidem, k. 47.

${ }^{36} \mathrm{ZNiO}$, sygn. 15587: M. B a n a c h, op. cit., k. 5-6.

${ }^{37}$ С. А б р а га м о в с ъ к а, Моїрідні Микулиниі - весня немістомого дитинства [w:] Шляхами Золотого Поділля, Тернопільщина і Скалатщина. Регіональний Історично-мемуарний, збірник, т. 3, Філядельфія-Нью-Йорк-Париж-Сідней-Торонто 1983, s. 762-763.

38 Zob. m.in. „Gazeta Przemyska” 1887, nr 2, 3.

${ }^{39} \mathrm{ZNiO}$, sygn. 15393: S. O t o w s ki, op. cit., k. 41.

40 ZNiO, sygn. 15394: T. Porembalski, op. cit., k. 47. 
żąc do polskich towarzystw, musieli przestrzegać zasad ustalonych przez ich polskie zarządy i we wzajemnych kontaktach używać języka polskiego ${ }^{41}$. Często też Polacy, władający swobodnie językiem ruskim, zapisywali się do ruskich stowarzyszeń kulturalno-oświatowych, które początkowo z powodu braku własnych lokali organizowały swoje imprezy w siedzibach polskich towarzystw. Dla przykładu - w Borszczowie aż do czasu wybudowania Narodnego Domu (co nastąpiło w 1909 r.) czytelnia „Proświty” organizowane przez siebie przedstawienia amatorskie wystawiała w sali polskiego „Sokoła”. Uczestniczyła w nich zresztą publiczność różnych wyznańn ${ }^{42}$. O uczestnictwie Polaków, a także Żydów, w ruskich przedsięwzięciach kulturalnych różnego typu wspomina między innymi cytowana już Stefania Abrahamowska ${ }^{43}$.

Ostatnie lata XIX wieku przyniosły niepokojącą zmianę w stosunkach między Polakami a Rusinami, przy czym od razu trzeba dodać, że w przypadku Polaków sprawy narodowościowe zaprzątały głównie uwagę osób należących do „wyższych warstw społeczeństwa”. Ludzi stojących na niższych szczeblach drabiny społecznej nie bardzo to wszystko obchodziło. W tych miejscowościach, w których przeważali Rusini, Polacy (łacinnicy) ulegali ich wpływom, zatracając znajomość języka polskiego. Łamaną polszczyzną posługiwali się w rozmowach z księdzem rzymskokatolickim, natomiast w domu i w życiu codziennym używali języka ruskiego, przejmowali ruskie obyczaje i zwyczaje domowe. Zarząd Główny Towarzystwa Szkoły Ludowej (a przypomnijmy, że stowarzyszenie to znajdowało się pod wpływem narodowych demokratów) już pod koniec XIX wieku alarmował, że następuje „systematyczne i groźne wynaradawianie mas ludności polskiej”, nie tylko mieszkańców wsi, ale również miast, gdyż - jak pisano - „mylne jest przekonanie, że miasta we Wschodniej Galicji są polskie". Wprawdzie w powiatach leżących w części środkowo-północnej istnieje grupa miast i miasteczek „poniekąd spolszczonych”, ale na Pokuciu i Podolu wpływ żywiołu ruskiego jest bardzo silny ${ }^{44}$, co wiązano z nasileniem działań o wydźwięku narodowym, podejmowanych przez narodowców ukraińskich. Już na początku lat 90. XIX wieku w małych miastach i miasteczkach zaczęły powstawać czytelnie „Proświty”, a nieco później, pod koniec lat 90., rozpoczęły działalność: „Sokił”, „Sicz”, towarzystwa kredytowe, kasy zaliczkowe, spółki spożywcze, „Narodna Torhowla”, wreszcie organizacja „Narodny Dom”, będąca drugim po „Proświcie” ośrodkiem ukraińskiego ruchu narodowego. „Proświta” powstała w grudniu 1868 roku i była dla Rusinów tym, czym dla Polaków Towarzystwo Szkoły Ludowej. Mimo że funkcjonowała w trudnych warunkach społeczno-politycznych i ekonomicznych, przez cały okres swego istnienia realizowała bogaty program pracy kulturalno-oświatowej, doprowadzając do społecznego i narodowego awansu Rusinów.

${ }^{41}$ ZNiO, sygn. 15395: J. P o r e m b al s k i, Moja praca w TSL. Wspomnienia, k. 5.

42 I. С ко ч и я с, Історія борщівської „Просвітии”, „Літопис Борщівщини” 1993, вип. 2, s. 26.

${ }^{43}$ С. Абрагамовська, op. cit., s. 765.

44 JiŁ [J. Łok i etek], Stosunki narodowościowe w Galicji Wschodniej. I. Archidiecezja lwowska obrządku rzymskokatolickiego [Odbitka z „Nowej Reformy”], Kraków 1894, s. 46, 54-55, 66-76, 94-95. 
Ukraińscy działacze narodowi wykonali ogromną pracę - w stosunkowo niedługim czasie zmienili polityczne i kulturalne oblicze swoich pobratymców zamieszkujących Galicję Wschodnią. „Wschodnia Galicja pokryta jest dzisiaj - pisał na początku XX wieku Wilhelm Feldman - siecią tysięcy czytelń ludowych, sklepów narodnych, agencji asekuracyjnych narodowego «Dnistra», biur banku narodowego [...], święci co roku publicznie uroczystości poetów narodowych, z każdym dniem pomnaża kadry inteligencji narodowej”, która „zapełnia coraz więcej urzędów publicznych, w każdym mieście i miasteczku wschodniej Galicji ma swoje odrębne kluby, czytuje własne dzienniki polityczne, własne czasopisma pedagogiczne, lekarskie, prawnicze $[\ldots]$. Ma dalej ta inteligencja swoje «Besidy», towarzystwa gimnastyczne, «Bojany» [...]. Żyjąc w bezustannym podnieceniu politycznym, bezustannie zwołuje wiece polityczne, na których inteligencja miesza się z chłopami”"45. Wszystko to powodowało, że wśród Polaków, którzy przez cały XIX wiek czuli się „właścicielami” Galicji Wschodniej, jej jedynymi pełnoprawnymi gospodarzami, powoli, ale wyraźnie narastał niepokój, zwłaszcza wobec coraz głośniejszego domagania się przez Rusinów praw politycznych i podziału Galicji na polską i ukraińską ${ }^{46}$. Narodowcy polscy, którzy podobnie jak działacze ukraińscy prowadzili na terenie Galicji Wschodniej szeroką działalność narodową, polegającą na popieraniu „oświaty, polskiego handlu, rolnictwa, przemysłu i pracy [...], stworzeniu praw narodowych w szkolnictwie i urzędach", zaczęli głośno apelować, aby jak najszybciej zastanowić się nad środkami obrony , już nie politycznego stanu posiadania, ale egzystencji naszej narodowej na wschodzie kraju" ${ }^{\prime 4}$.

W małych miastach alarm ten wszczęto z pewnym opóźnieniem, kiedy wyraźniej zaznaczać się tu zaczęła działalność narodowców ukraińskich.Wprawdzie do otwartych scysji nie dochodziło, jednakże konflikt narodowościowy wyraźnie narastał, zwłaszcza po zamachu na namiestnika Galicji Andrzeja Potockiego w kwietniu 1908 roku. Z niechęcią zaczęto się odnosić do osób pozostających w mieszanych związkach małżeńskich, skończyła się dotychczasowa współpraca w różnego rodzaju towarzystwach i organizacjach. Znajduje to odbicie w przywoływanych przeze mnie wspomnieniach mieszkańców małych wschodniogalicyjskich miast, którzy winnych pogorszenia stosunków między obiema narodowościami szukali wśród „agitatorów i prowodyrów ruskich”, zapowiadających „najzawziętszą walkę i użycie najskrajniejszych sposobów przeciw Polakom”, aby odzyskać „biedną naszą ruską ziemię”, poniewieraną i prześladowaną przez Polaków ${ }^{48}$. W polskiej prasie prowincjonalnej zaczęły się pojawiać teksty o Rusinach, którzy „,nas atakują na całej linii [...] i impetem biorą nam naszą dotychczasową własność" 4 .

45 W. Feldman, Stronnictwa i programy polityczne w Galicji 1846-1906, t. 2, Kraków 1907, s. $41-342$.

46 Zоb. „Dіло” 1911, nr 174.

47 S. Kasznica, Skład wyznaniowy wschodnio-galicyjskiego ciała sędziowskiego, Lwów 1908, s. 19.

48 Zob. „Kurier Stanisławowski” 1906, nr 1059; także: „San” 1879, nr 22.

49 Zob. „Tygodnik Ziemi Sanockiej” 1910, nr 24, także niektóre numery „Kuriera Stanisławowskiego" z 1910 r. 
W rezultacie upowszechnienia idei narodowych dotychczasowe więzi łączące Polaków i Rusinów w ramach sąsiedzkich wspólnot lokalnych zostały zerwane, a przynajmniej mocno osłabione. Mieszkańcy małych miast galicyjskich przestawali być drohobyczaninami, borszczowianinami, bolechowianami, sąsiadami z Brzozowa, Leska, Mikuliniec, Zabłotowa, Jagielnicy czy Kopyczyniec; stawali się Polakami i Ukraińcami, bez - co pokazała historia - wspólnej przyszłości.

\section{BIBLIOGRAFIA}

\section{I. Źródła}

\section{1. Źródła archiwalne}

Zakład Narodowy im. Ossolińskich we Wrocławiu (ZNiO):

sygn. 15327/1: M. B arański, Opowieść o jednym miasteczku i jednej rodzinie [Wspomnienia obejmujące okres od połowy XIX w. do 1978 r.], cz. 1. sygn. 15393: S. O tow sk i, Moje wspomnienia [z lat 1896-1963]. sygn. 15394: T. P or e m ba ls k i, Wspomnienia [z lat 1896-1960], t. 1. sygn. 15395: J. P or e m b a lsk i, Moja praca w TSL. Wspomnienia. sygn. 15450: T. F a bi a ń ski, Ze wspomnień bolechowskich. sygn. 15587: M. B a n a c h, Wspomnienia z lat 1897-1969, t. 1, vol. 2.

\section{Wspomnienia}

B o r o d z i c z J., Na Rusi galicyjskiej schyzma się gotuje!: z pamiętników..., Chrzanów 1911. Czech ow ic z A., Droga do szkoty [w:] Gimnazjum i Liceum im. Henryka Sienkiewicza w Eańcucie. Szkice historyczne, sylwetki, wspomnienia, Warszawa 1965, s. 234-254.

Doboszyński J., Pamiętnik [w:] Pamiętniki urzędników galicyjskich, przyg. do dr. I. Homola, B. Łopuszański, Kraków 1978, s. 359-416.

D u n in B or kow sk i A., Sejm ustawodawczy rakuski ze szczególniejsza uwaga na poselstwo polskie, cz. 2, Poznań 1850.

K[a rw o w s k i] St., Cztery tygodnie w Galicji, Poznan 1891.

Orło w i c z M., Moje wspomnienia turystyczne,Wrocław-Warszawa-Kraków 1970.

S ing e r I., ...poeta wygnania [wywiad przedrukowany z „Le Monde”], „Polityka” R. 26, 1982 , nr 40, s. 9.

Składzi eń J., Za ciasnym wydawał mi się ten zakatek. Pamiętniki, Kraków 1982. Zi e mi ałkow s ki F., Pamiętniki, cz. 1, 4, Kraków 1904.

Абрагамовсъка С., Моїрідні Микулинщі - весня немістомого дитинства [w:] Шляхами Золотого Поділля, Тернопільщина і Скалатщина. Регіональний Історично-мемуарний збірник, т. 3, Філядельфія-Нью-Йорк-Париж-Сідней-Торонто 1983, s. 762-765. 


\section{Dzieła literackie}

A u de r s k a H., Ptasi gościniec, Warszawa 1979.

Ch ci u k A., Atlantyda. Opowieść o Wielkim Księstwie Bałaku, Łomianki 2015.

Stryjk ow ski J., Przybysz z Narbony, Warszawa 1983.

\section{Prasa}

„Gazeta Podkarpacka” 1875.

„Gazeta Przemyska” 1887.

„Kurier Rzeszowski” 1889.

„Kurier Stanisławowski” 1906, 1910.

„San” 1879.

„Sądeczanin” 1902.

„Tygodnik Ziemi Sanockiej” 1910.

„ріло” 1911.

\section{Opracowania}

B e r 1 in I., Żydzi-od zniewolenia do emancypacji, „Znak” R. 35, 1983, nr 2-3, s. 481-500. F e ld m a n W., Stronnictwa i programy polityczne w Galicji 1846-1906, t. 2, Kraków 1907. Fras Z., Florian Ziemiałkowski (1817-1900). Biografia polityczna, Wrocław-WarszawaKraków 1991.

Goldberg-Mulki ew ic z O., Księga pamięci (,,Memorbuecher”) a mit żydowskiego miasteczka, „Etnografia Polska” 1991, t. 35, z. 2, s. 187-198.

Goldberg-Mulkiewicz O., Stara i nowa ojczyzna. Ślady kultury Żydów polskich, Łódź 2003.

H o ff J., Mieszkańcy małych miast Galicji Wschodniej w okresie autonomicznym, Rzeszów 2005.

Ho ff J., Społeczność małego miasta galicyjskiego w dobie autonomii, Rzeszów 1992.

Holze r J., Asymilacja i akulturacja Żydów galicyjskich, „Więź” R. 32, 1989, nr 4, s. 101112.

JiŁ [J. Łokietek], Stosunki narodowościowe w Galicji Wschodniej. I. Archidiecezja lwowska obrządku rzymskokatolickiego [Odbitka z „Nowej Reformy”], Kraków 1894.

Kasznica S., Skład wyznaniowy wschodnio-galicyjskiego ciała sędziowskiego, Lwów 1908.

Szatrawski K.D., Życie i tradycja Żydów w powieściach galicyjskich Juliana Stryjkowskiego [w:] Kresy i pogranicza. Historia, kultura, obyczaje, red. nauk. Z. F ra s, A. S t a n is zew ski, Olsztyn 1995, s. 207-225.

S zy m c zak - H off J., Życie towarzyskie i kulturalne Rzeszowa w dobie autonomii Galicji, Rzeszów 1993.

Świątek A., Gente Rutheni, natione Poloni. Z dziejów Rusinów narodowości polskiej w Galicji, Kraków 2014.

Скочиляс I., Iсторія борщівської „Просвітии”, „Літопис Борщівщини” 1993, вип. 2, s. 21-31. 